\title{
Weed finds as indicators for the cultivation regime of the early Neolithic Bandkeramik culture?
}

\author{
Angela Kreuz $\cdot$ Eva Schäfer
}

Received: 8 September 2010/ Accepted: 5 April 2011/Published online: 21 July 2011

(C) The Author(s) 2011. This article is published with open access at Springerlink.com

\begin{abstract}
Ethnographic data combined with the characteristics of the weed species from Bandkeramik settlement sites give hints for the reconstruction of Early Neolithic agricultural practises in Central Europe. In contrast to the Balkan situation with a high diversity in cultivated crops, Bandkeramik field management can be reconstructed as a simple agricultural system with emphasis on summer crop growing. Permanent fields were treated with hoes, digging sticks or similar tools, sown in spring and grazed in autumn and winter. The intensity of field management seems to increase through time as shown by diachrone comparison of archaeobotanical data from Neolithic, Iron Age and Roman times. The absence of winter-cereals such as naked wheat, grown in the Balkan Peninsula, gives a hint of a certain emphasis on stock breeding. Summer crop growing would have had the advantage that the Bandkeramik fields could be grazed after harvest until next spring and would therefore be manured at the same time.
\end{abstract}

Keywords Central Europe - Early Neolithic ·

Bandkeramik · Potential weeds - Intensity of cultivation

Communicated by C. C. Bakels.

\footnotetext{
A. Kreuz $(\bowtie) \cdot$ E. Schäfer

Landesamt für Denkmalpflege Hessen, Archäologische und Paläontologische Denkmalpflege, SG NaturwissenschaftenArchäobotanik, Schloß Biebrich/Ostflügel, 65203 Wiesbaden, Germany

e-mail: a.kreuz@denkmalpflege-hessen.de

E. Schäfer

e-mail: e.schaefer@denkmalpflege-hessen.de
}

\section{Introduction}

During the second half of the sixth millennium в.c. a new farming system occurred in western Hungary and beyond. In contrast to the cultural groups of the Starčevo-KörösCriş complex and its transition phase of south-west and eastern Hungary and south-eastern Europe, in Transdanubia the farmers belonging to the Bandkeramik culture started cultivating a crop spectrum that was reduced to half that occuring in the Balkan agriculture (Kreuz 2007; Kreuz in press; Kreuz et al. 2005).

Early Neolithic crop growing has been interpreted by other authors as small scale, intensive garden cultivation. Examples of this are Halstead (1981, pp. 319-334) "small scale, stable gardening with crop rotation and regular manuring" and Bakels (1978, p. 77) "The fields on which the plants were grown, were of small size and lay between tall vegetation. It is not clear whether they were used for a short time or for a long period." Further examples are Gregg (1988, pp. 98, 132) "small, scattered fields" for cereals and "small garden plots" for legumes and oil plants and Bogaard (2004, p. 160) "intensive garden cultivation of fixed plots that were sown in the autumn" (for the discussion see also Lüning 2000, pp. 181ff; van der Veen 2005; Willerding 1980, 1988). Today small scale intensive garden cultivation still can be found in the tropics for example, where high yielding crops like manioc or plantain are grown effectively on several levels on small garden plots. Here intensive management of the plots is necessary as these crops grow slowly and are planted relatively large distances apart. Due to the high yields (manioc up to 25 t/ha; http://fdcl-berlin.de/publikationen/fdcl-veroeffentlich ungen/agroenergie-glossar/maniok-agroenergie-glossar-fdcl; plantain up to 400 bananas per plant; http://www.der-gar ten.eu/gartenpflanzen/bananenpflanze.html) of the crops 
grown, the work involved in hoeing and weeding the spaces between the individual plants is worthwhile. In contrast, the Bandkeramik situation would be different as the Bandkeramik cereals pulses and oil/fibre plants are not so high yielding. In addition, in the case of a group of merely ten people, which is much less than assumed for a Bandkeramik hamlet, cereal field areas of about five hectares would have been needed ( 0.5 ha/capita, Kreuz in press, chap. 8). Calculated without fallow this is an area of at least five football grounds and appears to be more a park than a garden. It has already been concluded by Lüning that Neolithic cereal growing was practised on areas beyond the space of a garden: “... deren Größenordnung über einen Gartenbau hinausging" Lüning (2000, p. 181). Therefore the whole subject merits further discussion.

Field management tools and related practices

The Bandkeramik farmers colonized chernozem areas ideal for crop cultivation. Due to these fertile soils and the assumed weather conditions at Bandkeramik times no shifting cultivation or irrigation, but rather permanent fields on terrestrial soils outside the river valleys might be expected (Bogaard 2002, 2004). In addition manuring by the grazing animals after harvest combined with crop rotation might have been sufficient for the nutrient regime of the crops grown. This fits with the fact that the Bandkeramik weed species found regularly in the samples, such as Bromus cf. secalinus, Chenopodium album, Galium cf. aparine, G. spurium, Lapsana communis, Phleum pratense, Polygonum convolvulus, Setaria-species, Solanum nigrum etc. grow on nitrogen-rich sites today.

Following Sherratt (1981, 1983), Fries (1995, p. 169) and the state of archaeozoological research (Arbogast et al. 2001; Benecke 1994, pp. 142ff.) the management of the fields was performed by hand without ploughs (for discussion and further references see Kreuz in press, chap. 7). Possible tools were hoes and all kinds of digging sticks. Ethnographic documentation reveals that one person would be able to dig an area of half a hectare within 2-3 weeks (Kreuz in press, chap. 7). Half a hectare is the area needed for yearly crop growing per person. Therefore it is evident from the ethnographic data that working the fields without plough should have been no problem. In addition, as shown by modern examples from bio-farming and archaeobiological experiments (Holzer 2008; Jacomet and Schibler 2007; Reynolds 1979, p. 53), pigs could have been used to break up the soil, especially if attracted by some grain or pulses spread on the ground. An additional advantage of this practice is that they would also eat the rootstocks of weeds as well as snails, insects etc.

It is clear that sowing the seed had to be done in rows, as broadcast sowing requires harrowing after ploughing to prepare an even soil. Cereals and pulses germinate in the dark, so the seed corn would have to be covered by earth. In Bandkeramik times the easiest way would have been one person placing the seed in the soil followed by another person covering it with earth with their feet. Independent of the tools and methods of ploughing, it is always necessary to hoe and loosen the soil several times in April and May to prevent weeds from growing. For this weeding likewise it is practical to have sown the crop in rows. It is a paradox that working the land with sticks, hoes or whatever always favours the weeds by spreading fragments of runners, tubers, rhizomes etc. and bringing seeds into the light.

The type and intensity of fieldwork and the indispensable practice of crop rotation (Pflanzliche Erzeugung 1998, p. 87) had to be adapted to the specific needs of the different crop species. For example flax (Linum usitatissimum) and poppy (Papaver somniferum) are much more demanding than the glume wheats, and flax ought to be grown on the same plot only every 7 years. The growing of einkorn (Triticum monococcum) and emmer (T. dicoccum) as maslins (for the definition see Jones and Halstead 1995) is not very probable, as these cereals ripen at different times (einkorn somewhat later), when sown simultaneously. Today these wheat species have different growth heights, and if grown together the rather delicate einkorn plants would be shaded too much by the stronger emmer plants (W. Planz, 2009, Demeter-farm Gau-Algesheim/ Rhinehesse, "personal communication").

On account of the growth height of the weed species earharvesting was probably practised by the farmers during the first half of the Bandkeramik culture (Kreuz 2007). This method avoids the harvesting of most weeds. Only the climbing weeds like Polygonum convolvulus or Galium species are difficult to avoid (see also Bogaard 2004). The increase of weed species, especially the low growing taxa, during the second half of the Bandkeramik period can probably be explained amongst other things by the switch to sickle harvesting which occurred then (Kreuz in press, chap. 6; Fig. 5).

After the description of materials and methods that follows, some hypotheses concerning sowing time and field cultivation will be discussed based on the archaeobotanical data.

\section{Materials and methods}

Our data presented here (Table 1) comprise the results from 15 Earliest Bandkeramik (LBK I) and 24 Younger Bandkeramik sites (LBK II-V; LBK-phases following Meier-Arendt 1966). 546 features were investigated and revealed 478,505 plant remains from 169 plant species (without charcoal). Amongst the excavated feature types, 
waste pits are the locations where everyday rubbish might have been deposited. As this feature type could give a representative average of routine as well as occasionally occurring settlement activities, and to compare like with like, our calculations are based mainly on the results from 519 Bandkeramik waste pits. The Early Neolithic data are compared with those from 34 pre-Roman Iron Age Celtic and 15 Roman Period Germanic sites (342 pit features). Due to soil conditions only charred and mineralized plant remains are preserved. All calculations presented here are based on charred seeds or fruits and in parts chaff remains.

Only sites containing at least five weed species were included in the investigation of assemblages of plant remains from weed species with respect to their relative abundance. The program CANOCO was used for correspondence analysis (ter Braak and Šmilauer 2002).

Table 1 Ecological characteristics and parameters of the potential weed species included in the analysis. The species are arranged following the Ecological Groups. Data for the table according to the

\section{Results}

Archaeobotanical weed assemblages

The number of weed species and the number of weed finds is dependent on the crop processing practices (for the ethnographic evidence see e.g. Hillmann 1984 and Jones 1984 and the papers in Anderson et al. 2003 and Procopiou and Treuil 2002). To give an example: if the cereals had been sieved before charring we would get another spectrum of seeds than from that of the entire harvest. Our implication is that, for practical reasons, comparable processing practices were carried out by the different groups of prehistoric farmers. The archaeobotanical results show that spikelet dehusking and removing weeds on a household level was part of the daily meal preparation in the villages.

BIOLFLOR database (by Klotz et al. 2002), as well as to Brouwer and Stählin 1975; Kästner et al. 2001; Oberdorfer 1990a, 1990b; Korneck and Sukopp 1988 (explanation in the text)

\begin{tabular}{|c|c|c|}
\hline Abbreviation & Term & Explanation \\
\hline ReproType & Reproduction type & $\begin{array}{l}s \text { spreading by seed only, } s s v \text { mostly by seed, rarely vegetatively, } s v \text { by } \\
\text { seed and vegetatively, } v v s \text { vegetatively, rarely by seed, } v \text { vegetatively } \\
\text { only; empty cell: not specified, e.g. for taxa comprising several species }\end{array}$ \\
\hline ReproSum & $\begin{array}{l}\text { Reproduction types } \\
\text { classified } \\
\text { (see ReproType) }\end{array}$ & $\begin{array}{l}\text { ReproDia: s and ssv; ReproVeg: v and vvs; ReproDiaVeg: spreading by } \\
\text { seed and vegetatively; ? clear interpretation not possible }\end{array}$ \\
\hline VegDisp & $\begin{array}{l}\text { Organs for vegetative } \\
\text { propagation }\end{array}$ & $\begin{array}{l}a \text { runner, } a k \text { runner with tuberous tip, } b s \text { brood shoot, } p s \text { phyllogenous } \\
\text { shoot, } r h \text { rhizome, } r p \text { rhizome-like pleiocorm, sk shoot tuber, ws root } \\
\text { shoot; not listed if no vegetative dispersal }\end{array}$ \\
\hline VegDispD & $\begin{array}{l}\text { Mechanisms of vegetative } \\
\text { spread }\end{array}$ & $\begin{array}{l}V e g D \text { capable of vegetative propagation by dividuals }(\mathrm{a}, \mathrm{ak}, \mathrm{ar}, \mathrm{az}, \mathrm{b}, \mathrm{fr} \\
\mathrm{rh}, \mathrm{rp}) ; \mathrm{Veg} \text {, if capable of vegetative propagation without dividuals; no } \\
\text { vegetative propagation; ? unknown }\end{array}$ \\
\hline StratType & Strategy type & $\begin{array}{l}c \text { competitors, } c r \text { competitors/ruderals, } c s \text { competitors/stress-tolerators } \\
c s r \text { competitors/stress-tolerators/ruderals, } r \text { ruderals, } s \text { stress-tolerators, } \\
s r \text { stress-tolerators/ruderals; empty cell: not specified, interpretation not } \\
\text { possible }\end{array}$ \\
\hline Annual & Life span & $\begin{array}{l}\text { aus perennial, sum summer-annual, sum? probably summer-annual, win } \\
\text { winter-annual, ? clear interpretation not possible, empty cell: not } \\
\text { specified, mostly for taxa not found in our Neolithic sites }\end{array}$ \\
\hline SeedDim & Seed dimensions & $\begin{array}{l}\text { Maximum dimension of the diaspores: fine }<2 \mathrm{~mm} \text {; medium } 2-5 \mathrm{~mm} \text {; } \\
\text { coarse }>5 \mathrm{~mm} \text { (relating to the maximum dimension of diaspores } \\
\text { respectively);? interpretation not possible }\end{array}$ \\
\hline GrowthHeight & Growth height & $\begin{array}{l}\text { low } \leq 40 \mathrm{~cm}, \text { rather low } \leq 50 \mathrm{~cm}, \text { medium } 41-80 \mathrm{~cm} \text {, high }>80 \mathrm{~cm} \\
\text { low } / \text { medium = not high; ? empty cell: not specified, e.g. taxa } \\
\text { comprising several species }\end{array}$ \\
\hline ApoAnt & Apophyte/ anthropochore & $\begin{array}{l}A P O \text { apophyte, } A N T \text { anthropochore; ./. no information available; empty } \\
\text { cell: not specified, mostly for taxa not found in our Neolithic sites }\end{array}$ \\
\hline $\begin{array}{l}\text { Tramp } \\
\text { Mow } \\
\text { Past }\end{array}$ & $\begin{array}{l}\text { Trampling tolerance } \\
\text { Mowing tolerance } \\
\text { Grazing tolerance }\end{array}$ & $\begin{array}{l}u \text { intolerant (BF 1-3), } i \text { indifferent (BF 4), } v \text { tolerant (BF 5-9); o.A. taxa } \\
\text { comprising several species; empty cell: not specified as not listed in } \\
\text { BIOLFLOR }\end{array}$ \\
\hline
\end{tabular}




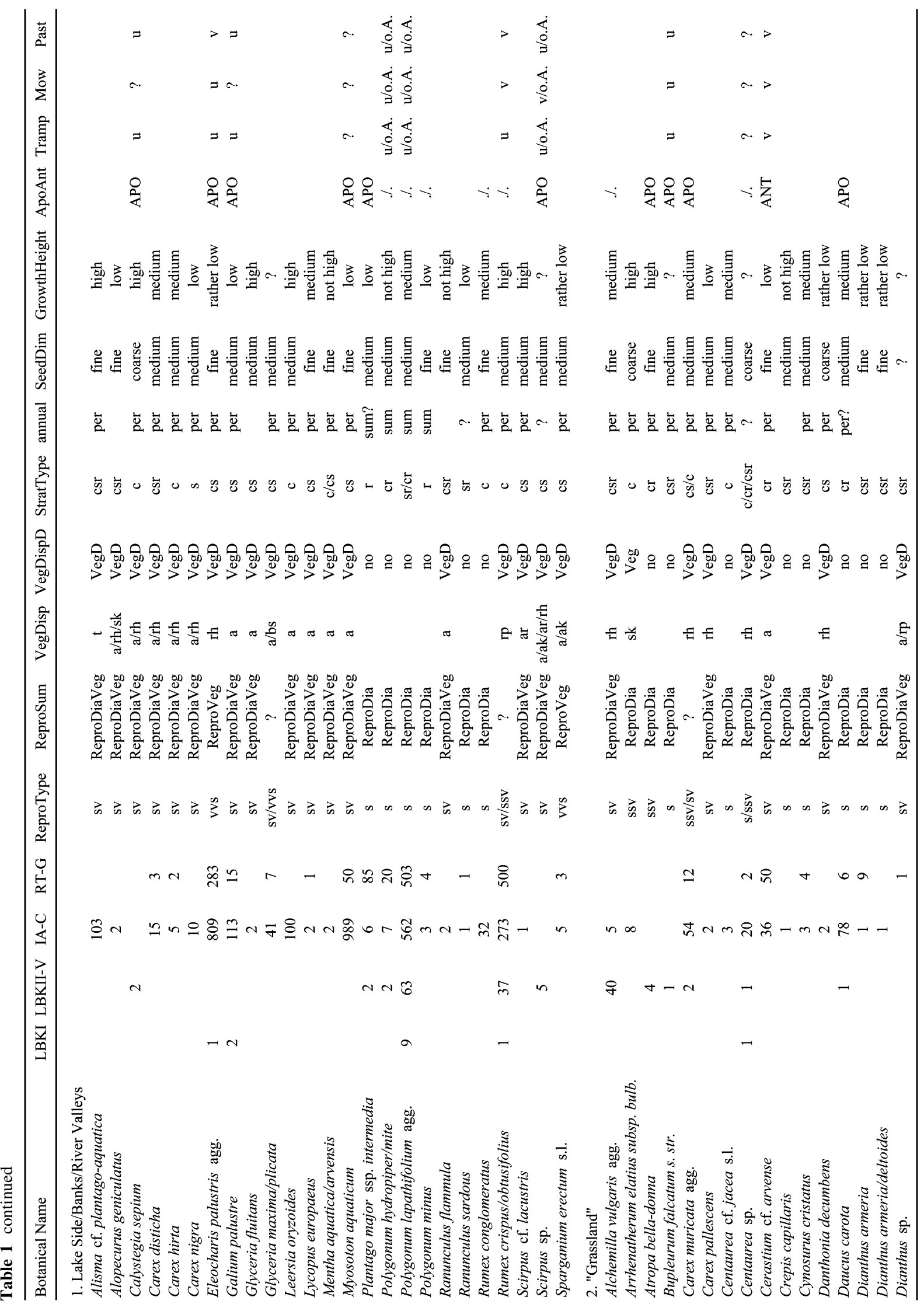




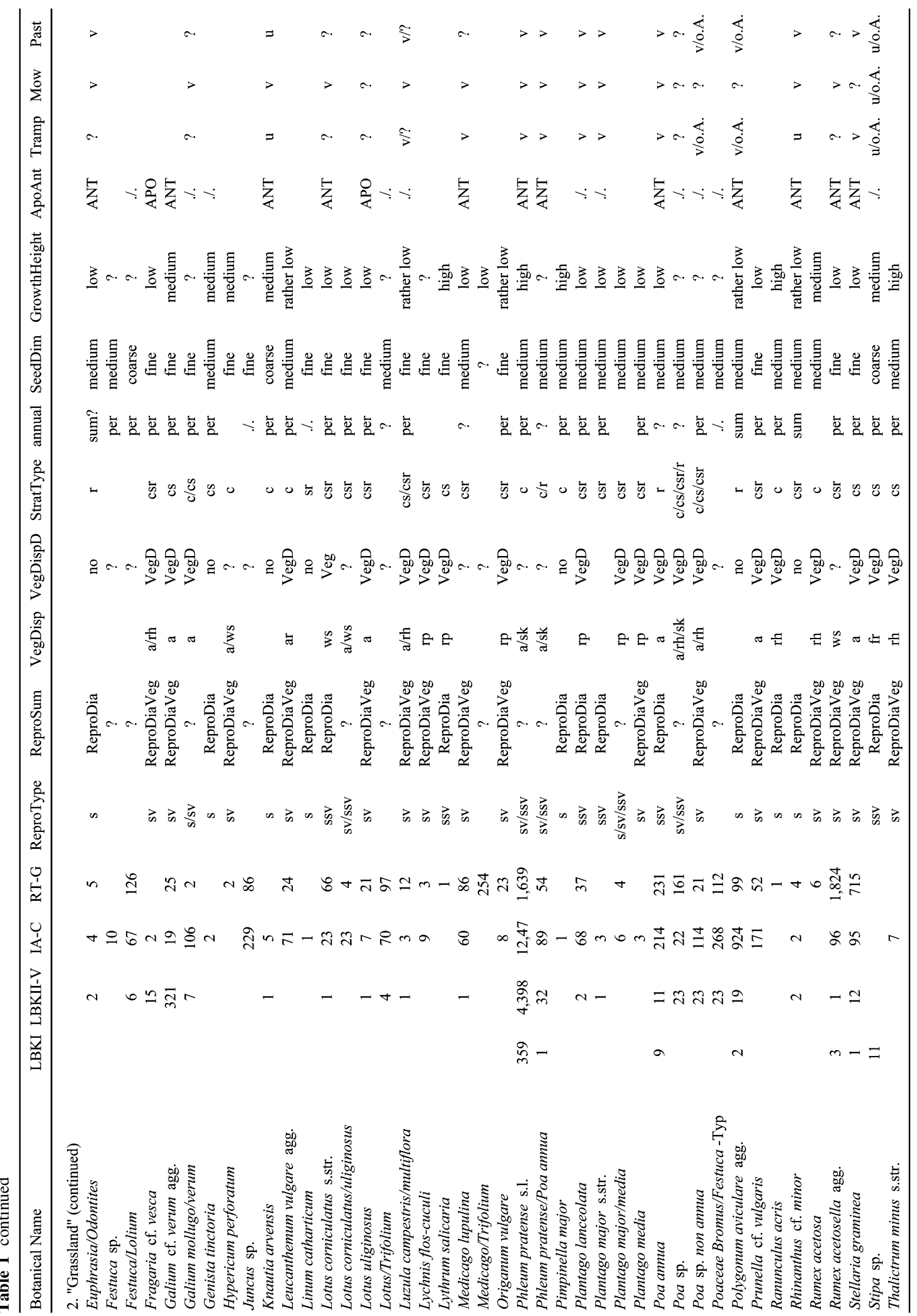




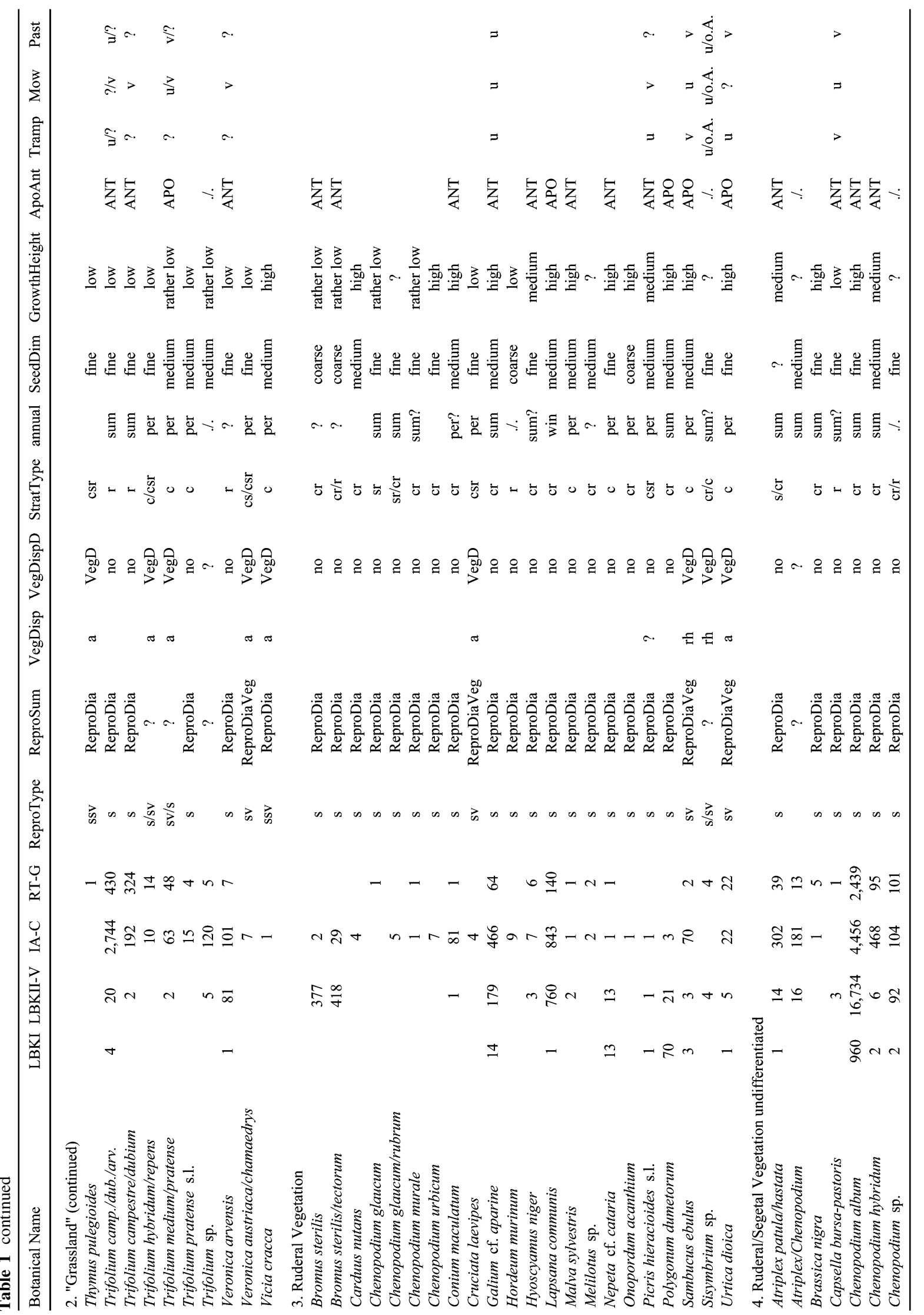




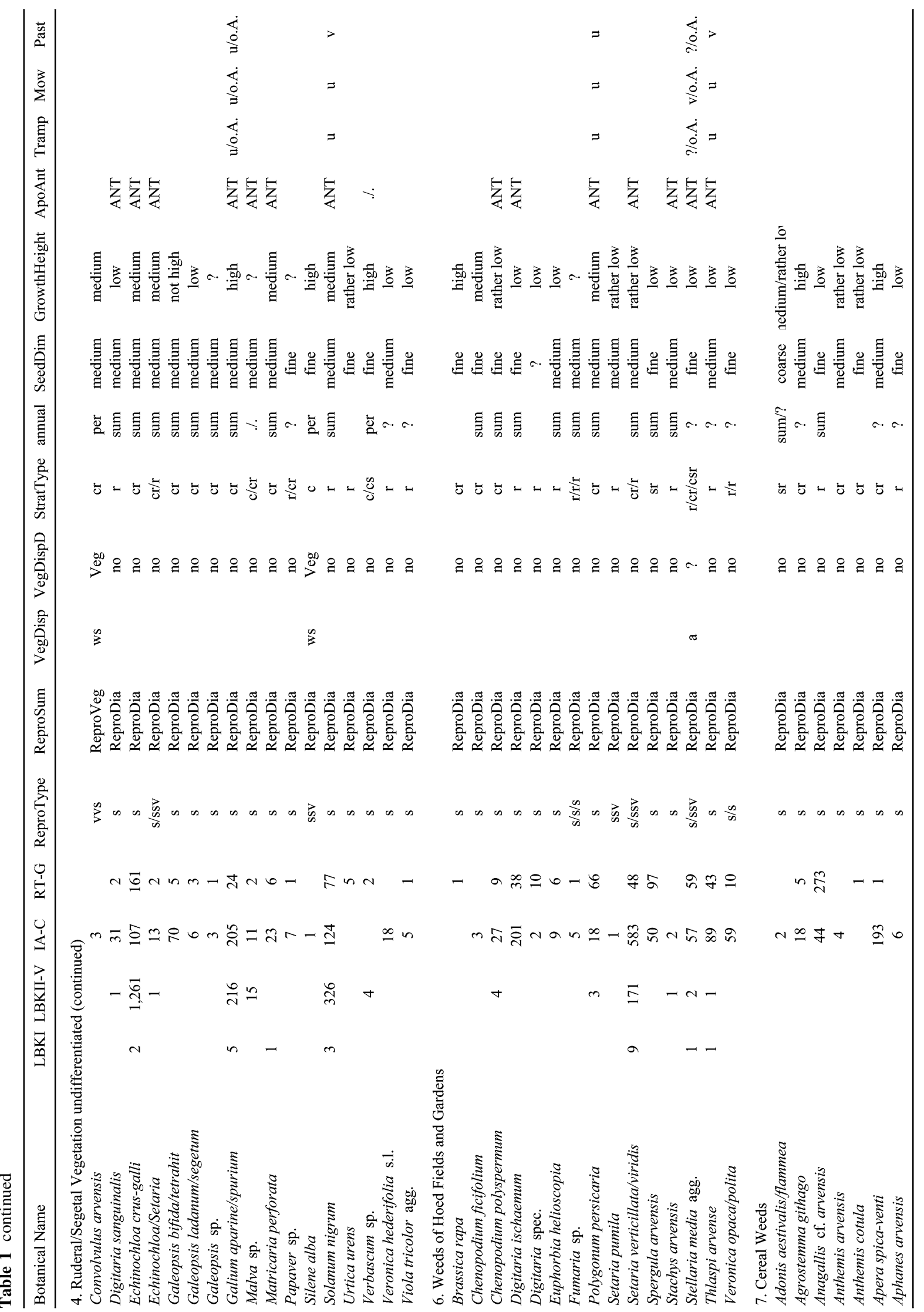




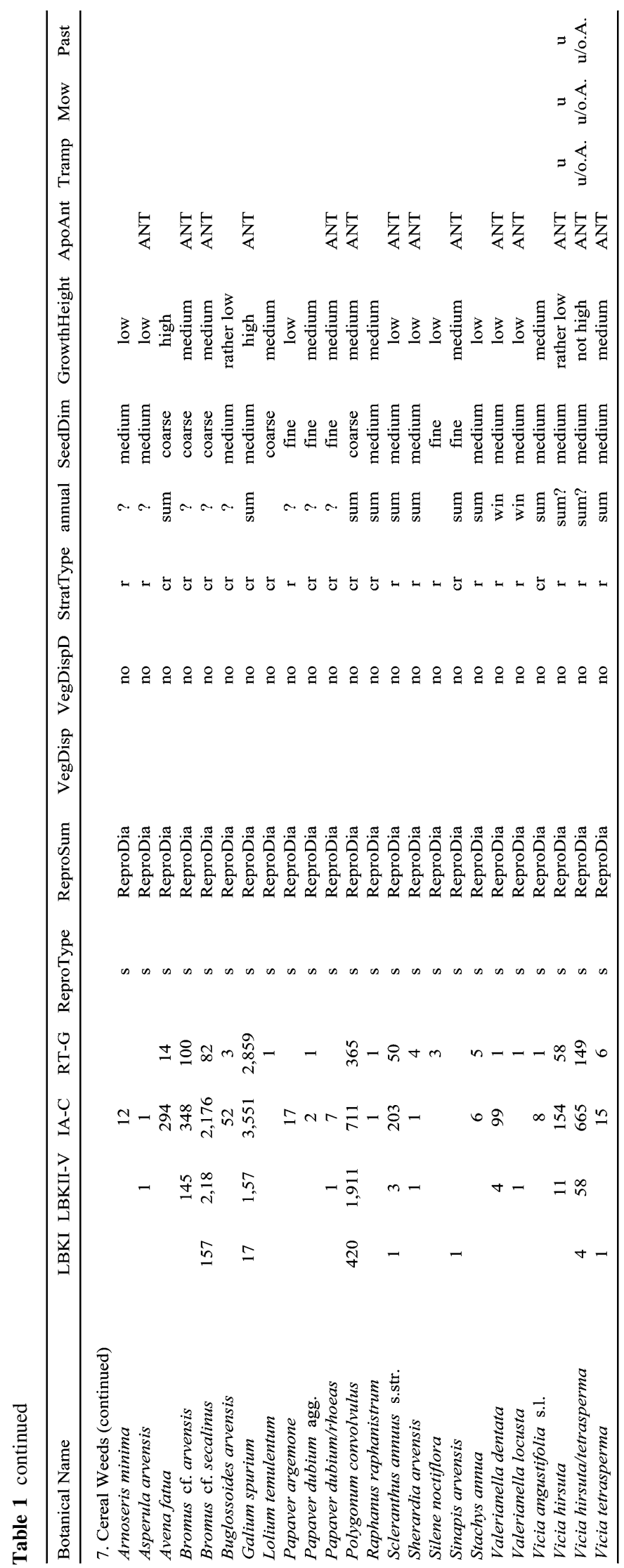


As shown by Kreuz and Schäfer (2008) and Bogaard (2004) for the Bandkeramik, Pre-Roman Iron Age and Roman periods the archaeobotanical samples represent mostly late processing stages, e.g. by-products of finesieving and hand-sorting for daily consumption. Therefore it is possible to consider for example the variation in weed composition, with particular attention to chronological developments, as the results very probably are not caused by mixing of completely different crop processing stages.

Concentrations of grain-rich finds-so-called storage finds of crops with associated weeds are rarely preserved at Bandkeramik sites. In 546 features (mostly pits) investigated archaeobotanically only two storage finds occurred. This might be a hint of a lower scale of agricultural production compared to more recent prehistoric periods (Kreuz in press, chap. 3).

Since storage finds are lacking, chorological and (aut)ecological data for each species are used to decide if a species found should be interpreted as a potential weed or not (Kreuz 1993 and references therein). The CentralEuropean flora comprises on one hand indigenous species, the idiochores, which entered a region without anthropogenic influence and help. Those able to establish themselves as ruderals or weeds in the settlements and fields are called apophytes. On the other hand there is a second group of the flora comprising the anthropochores which could only enter a region and persist by direct or indirect anthropogenic influence. We can expect that all anthropochores of the Neolithic were brought in with seeds during the colonization of the landscapes. Amongst the plant species found at our Bandkeramik sites all in all 90 potential weed taxa were identified; 54 taxa could be classified as introduced anthropochores and 16 as indigenous apophytes which can be considered as weeds in this context. In addition there were 20 potential weed taxa which could not be assigned to either group. From the total number of 90 potential weed taxa found in all our Bandkeramik sites, 39 were found in Earliest Bandkeramik sites (LBK I) whereas 84 taxa occurred in the Younger Bandkeramik settlements (LBK II-V). Interestingly, according to these results, during the second half of the Bandkeramik period the number of weed species increases considerably, a phenomenon which is discussed below in the context of field cultivation methods (Table 1; Fig. 1).

\section{Sowing time}

As the Early-Neolithic crop species originate from areas where the main precipitation is in winter, it appears reasonable winter-crop growing was practised there (e.g. Blumler and Waines 2009). This assumption has been made about the Bandkeramik farming system in Western

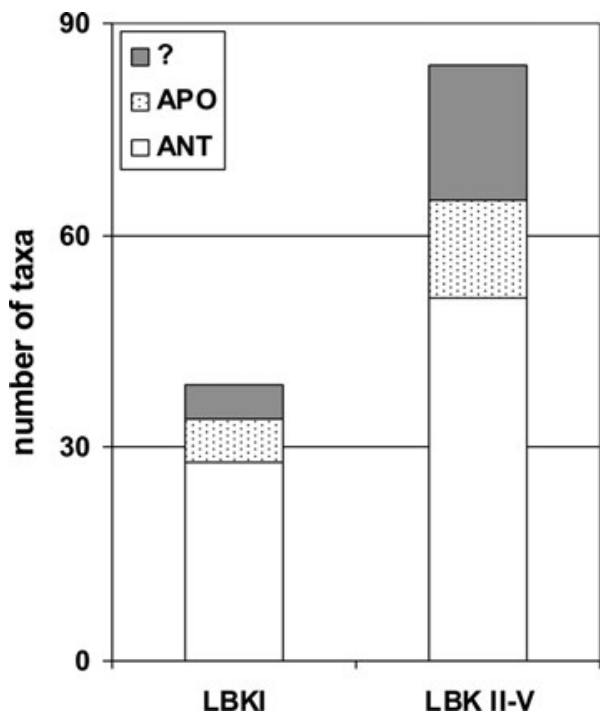

Fig. 1 Number of weed species differentiated into introduced anthropochores and indigenous potential weeds (apophytes) in features of the Early Neolithic Earliest Bandkeramik culture (LBK I) and following phases (LBK II-V)

Central Europe by different authors (e.g. Bogaard 2004; Willerding 1980). Instead of using modern plant sociological units like Secalietea and Chenopodietea for weed classification to reconstruct the sowing time as has been done by other authors, the genetically fixed character states of life form, life span and number of reproduction cycles of the species are taken into account in the following discussion. "In the reconstruction of Medieval plant communities one may frequently include modern associations for purposes of comparison. However, the farther one reaches back in time, the higher will be the hierarchical level in plant sociology that can serve for comparison." (Behre and Jacomet 1991, p. 83; see also Behre 1993, 1999. For the discussion of modern plant sociological units see Hüppe and Hofmeister 1990; we are working with Ecological Groups, see Kreuz 2005, p. 122 and Table 1. In our calculations genera-determinations are included, if all species indigenous today in our investigation area have the same ecological characteristics).

In 1,744 Bandkeramik soil samples from 546 features analyzed almost no winter-annuals were found, but predominantly summer-annuals were determined (Fig. 2; data from Kästner et al. 2001 and BIOLFLOR, see below). The only winter-annual species of the Bandkeramik period are Lapsana communis, Valerianella dentata and V. locusta. The latter two species each occurred only once in samples of the Younger Bandkeramik period. Lapsana communis is not a typical winter-cereal weed but more a ruderal plant, and maybe immigrated as an apophyt from hedges and edges of woodland surrounding the fields. Therefore the archaeobotanical evidence leads to the assumption that 


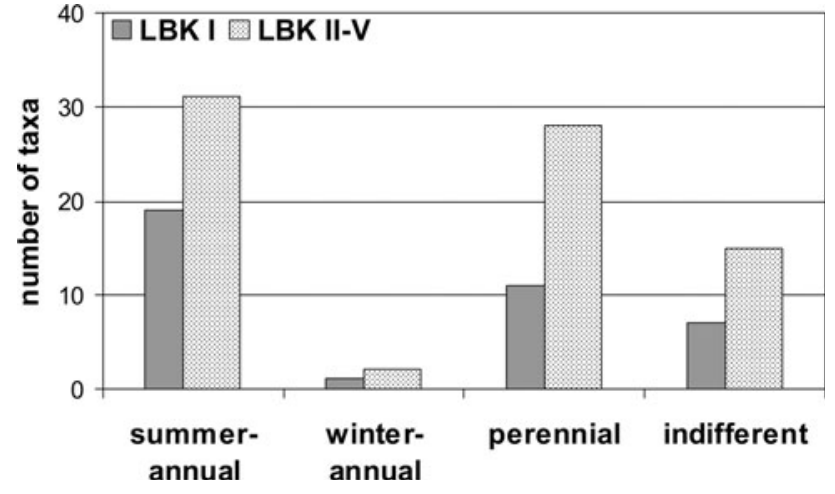

Fig. 2 The life forms of the potential Bandkeramik weed species are used as indicators for the sowing time of the Early Neolithic crops (explanations in the text, see also Table 1)

spring sown summer crops were cultivated by the Bandkeramik farmers (Kreuz 2007; Kreuz in press, chap. 3; Kreuz et al. 2005).

Following Bogaard (2004, p. 110ff.) weeds with small seeds from the by-product of fine-sieving distort the archaeobotanical result in terms of indicators of summercrop growing. Actually, the proportion of small-seeded weeds (max. $2 \mathrm{~mm}$ diameter) amongst the Bandkeramik evidence is less than 30\% (70\% are coarse and medium sized, see Table 1). These small-seeded species belong predominantly to the ecological group 2 "Grassland" and not to the "real weeds" of cereal fields and gardens considered by Bogaard (Table 1). Therefore, a connection between seed size, crop processing and sowing time cannot be confirmed here (Kreuz in press, chap. 6).

In this context it is of interest that most einkorn genotypes are fairly proof against winter but have no vernalisation requirements (in German "Wechselweizen”: Christof Kling, Hohenheim, 2010, "personal communication"; http://www. agfdt.de/loads/gt09/klingabb.pdf). Therefore einkorn can be grown as a summer or winter crop. There also exist summer and winter forms of emmer. Somewhere on the long way from Southwest Asia to Western Central Europe such properties could have been selected from the landraces of the cereals. Maybe this "Wechselweizen" property is one reason for the dominance of einkorn in Bandkeramik sites (Knörzer 1991; Kreuz 2007).

In the case of summer-crop growing, sowing the seed of einkorn, emmer and pea (Pisum sativum) starteddepending on the weather-at the beginning of March. Linseed (Linum usitatissimum) was sown at the end of March, subsequently followed by opium poppy (Papaver somniferum) and finally from the middle of April onwards by lentil (Lens culinaris). Summer-crop growing had the positive consequence of keeping the autumn free for collection of wild fruits and nuts and hunting, and all in all fieldwork was better distributed over the year. In addition livestock could graze the fields from autumn until field preparation in early spring, in the meantime manuring the soil (see below).

Intensity of field cultivation

In estimating the intensity of field cultivation, the type of reproduction, the ecological strategy types, as well as life and growth forms of the Bandkeramik weed species can be considered as indicators. The data concerned we owe to the BIOLFLOR-database (Klotz et al. 2002; Table 1).

The reproduction type (Reproduktionstyp) of the weed species is defined as the production of descendants, which are physically independent and separated from their parents (Durka 2002, p. 138). Genetically fixed weed species germinate from their seeds or fruits or they propagate and disperse vegetatively. It is notable that the "real weeds" of fields and gardens comprise primarily annual species spreading generatively with diaspores (Ecological Groups 6 and 7, Fig. 3; Table 1). The other potential weed species which today are classified as belonging to ruderal and especially floodplain and "Grassland" vegetation comprise naturally a higher proportion of vegetative propagating species (Ecological Groups 1-3, Fig. 3; for the interpretation of such taxa as weeds see Favre 2002, p. 165; Jacomet et al. 2004, p. 130; Maier 1999, p. 90; Rösch 2005; Stika 1999; Willerding 1988, p. 36).

Vegetative dispersing species as well as deep rooting ones (Tiefwurzler) are the most awkward weeds. Amongst this group the most effective propagation is shown by socalled runners (Ausläufer-Pflanzen) or species able to propagate by fragmentation, because they are fragmented and spread involuntarily by people hoeing or digging the soil.

As shown in the graphs, not more than $15-16 \%$ of the Bandkeramik weeds are able to disperse vegetatively, and these belong to the ecological groups 1-3 (Figs. 3, 4; Table 1). Two-thirds of the potential weeds are those with dispersal by seeds or fruits. The Bandkeramik results are compared with those from 135 pre Roman Iron Age Celtic and 91 Roman Period Germanic features (mostly pits). The percentages of reproduction types remain almost the same during the different prehistoric periods. There is just a slight increase of vegetative propagating species in the younger prehistoric periods (Fig. 4 below).

Interestingly the number of species belonging to the Ecological Group 2 "Grassland" increases over time (Fig. 3) and these species are mostly able to tolerate mowing by people and browsing and trampling by animals or they are at least indifferent to such disturbances (Table 1). If the fields were regularly grazed after harvest, species with these properties would have had an advantage. 
Fig. 3 Diachrone comparison of the number of potential weed species per Reproduction Type and per Ecological Group. Species spreading by diaspores (seeds/fruits) are differentiated from those spreading by diaspores and vegetatively and those spreading vegetatively only (explanation in the text, see also Table 1). Compared are data from Bandkeramik (LBK), pre-Roman Iron Age Celtic (IAC) and Roman Period Germanic (RT-G) pits. Ecological Groups: 1 Lake Side/Banks/River Valleys,

2 "Grassland",

3 Ruderal Vegetation,

4 Ruderal/Segetal Vegetation undifferentiated,

6 Weeds of hoed fields and gardens,

7 Cereal Weeds
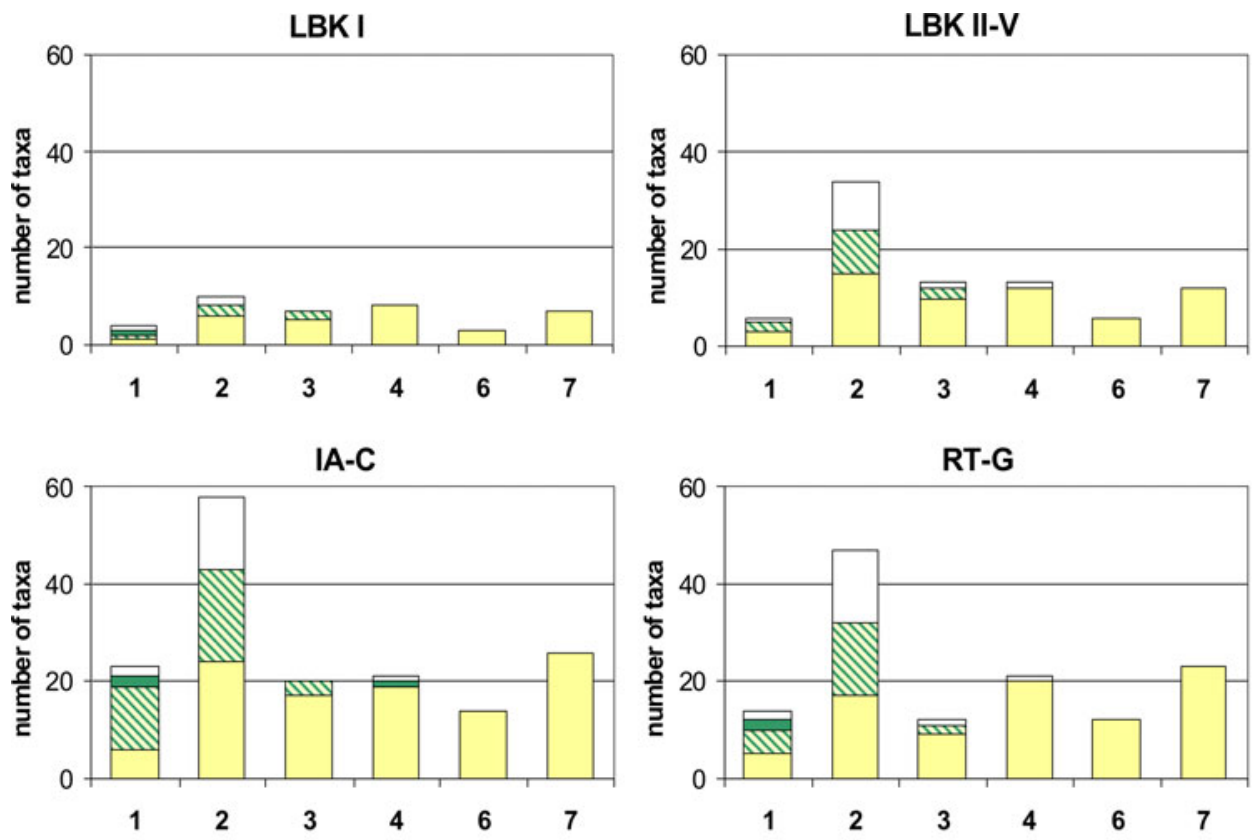

\section{$\square$ reproduction type diaspore $\square$ reproduction type vegetative}

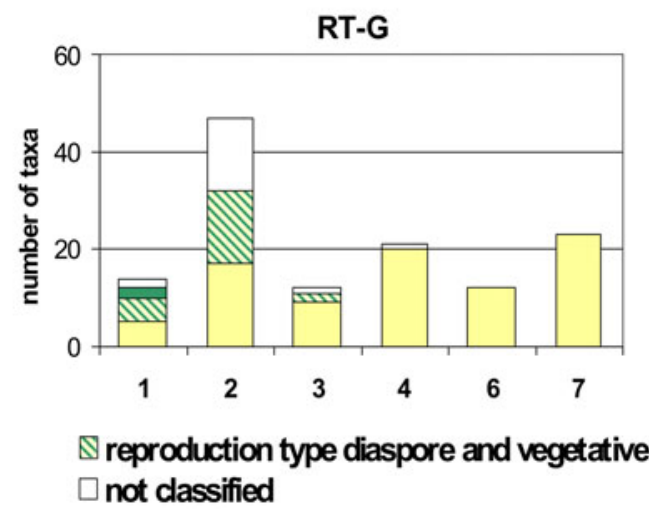

LBK I

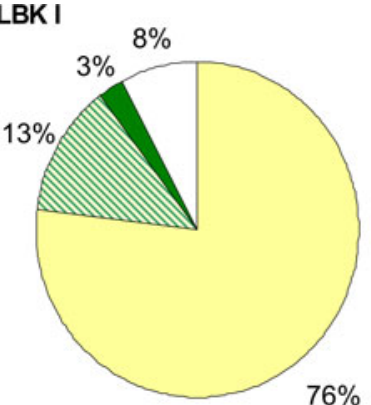

IA-C

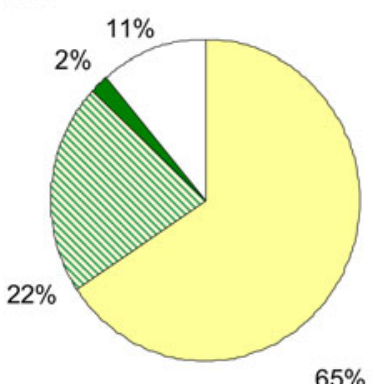

$65 \%$
LBKII-V

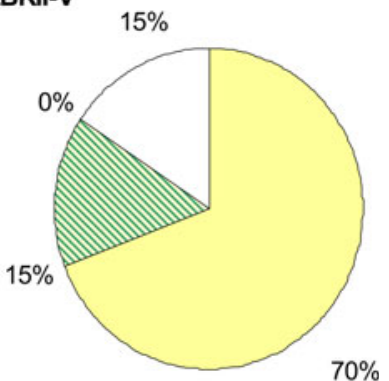

RT-G

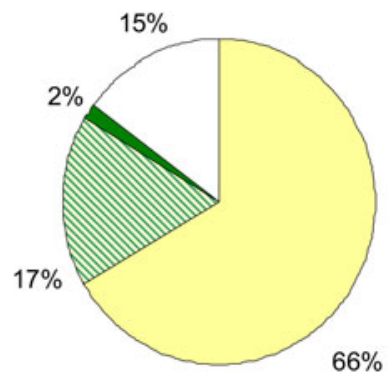

Perhaps their occurrence in our weed assemblages could be interpreted as the practice of grazing the stubble enduring over the millennia. At the same time this practice would have improved the manure-regime of the fields considerably (Bates 1973, p. 127; Ebersbach 2002, p. 133; ErtugYaras 1997, p. 223; Forbes 1998; Holzer 2008).

It is a fact that most of our weed species found which are able to propagate and disperse vegetatively are at the same time able to build dividuals (Dividuen) by fragmentation or

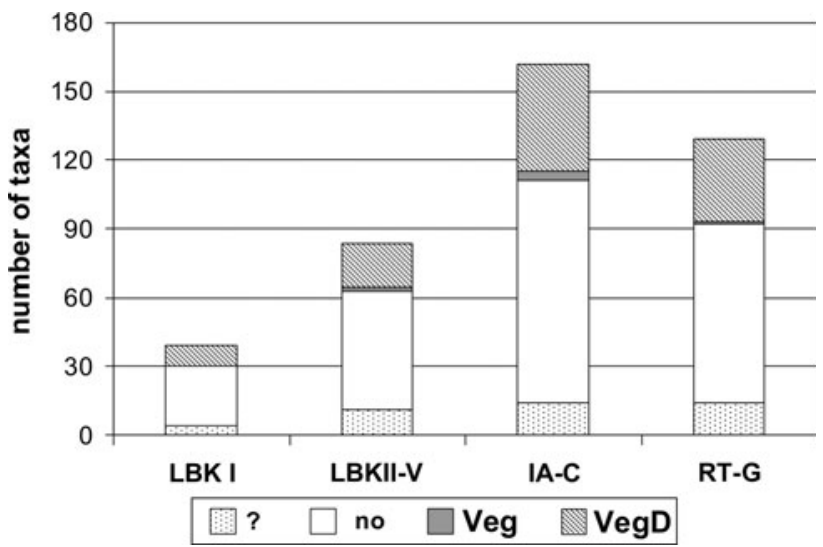

Fig. 5 Diachrone comparison of the number of potential weed taxa classified by their kind of vegetative propagation and dispersal. Veg vegetative dispersing without dividuals; $V e g D$ vegetative dispersing and able to build dividuals; no no vegetative propagation; ? not classified (data from BIOLFLOR, explanation in the text)

Fig. 4 Diachrone comparison of the percentages of Reproduction Types of the potential weed species (for explanation see legend Fig. 3) 
similar processes (Fig. 5). There exist different opinions concerning their interpretation as indicators on one hand of in part undisturbed fields (Willerding 1988, pp. 36ff), as opposed to intensively managed garden plots on the other (Bogaard 2004, pp. 125ff).

For this question among others, the diversity of the weed species is of interest. It is striking that there are rather few weed species found in the samples of the Earliest Bandkeramik culture (LBK I). The increase of species from phase LBK II (Flomborn, after Meier-Arendt 1966) onwards cannot be explained by the centuries of enduring cultivation, as there is almost never continuity between settlements (and therefore probably field areas too) of LBK phase I and II. One reason for the delimited weed spectrum might be the strategy of ear-harvesting, which allows the avoidance of many weeds. Instead, even more important for the interpretation seems to be the observation by Ellenberg (1950, pp. 94ff), who could demonstrate that the number of weed species growing in a "normally managed" field is seven times higher than in a neglected one. This is due to the fact that on neglected fields the thriving and often tall weeds are spreading in masses and suppress the small or slowly growing ones. Therefore it cannot be ruled out that the rather small number of Earliest Bandkeramik weed species is the consequence of a very simple and cursory field management at the beginning of the Neolithic combined with ear-harvesting. It was not until an intensification of field treatment during more recent prehistory took place that the number of weed species increased, for example to 167 in the Pre-Roman-Iron Age and Roman times, three to four times that in Bandkeramik times.

Strategy types of weeds

Concerning the intensity of field management it is interesting to consider the strategy type of the potential weeds (data from BIOLFLOR; strategy types developed by Klotz et al. 2002 from the systems of MacArthur and Wilson 1967; Grime 1974; Grime et al. 1988). To characterize the strategy type BIOLFLOR uses the following characteristics: life form, persistence and anatomy of leaves, maximum growth height, flowering period, floral and reproductive biology as well as the ecological indicator values (Zeigerwerte, after Ellenberg et al. 1991). This is comparable to the functional ecology parameters of the FIPS model by Jones et al. (2005).

Following BIOLFLOR the Bandkeramik weed species can be differentiated into several strategy types (Table 1). Important for our interpretation in terms of field management are the competitors and the ruderals. Ruderals (Ruderalstrategen) are mostly annual, herbaceous, low growing species, flowering quickly and producing many seeds. Today they are the typical weeds of cereal and of hoed fields and gardens (Secalietea, Chenopodietea). For our interpretation it is important that ruderals are often sensitive to shading and need highly disturbed stands with little competition. Therefore their proportion comprises not more than $8 \%$ of the natural flora (Klotz and Kühn 2002,
Fig. 6 Diachrone comparison of the number of taxa per Ecological Group, differentiated for their Strategy types (for explanation see legend Fig. 3). Note the increase in taxa in the Ecological Group 2 "Grassland"
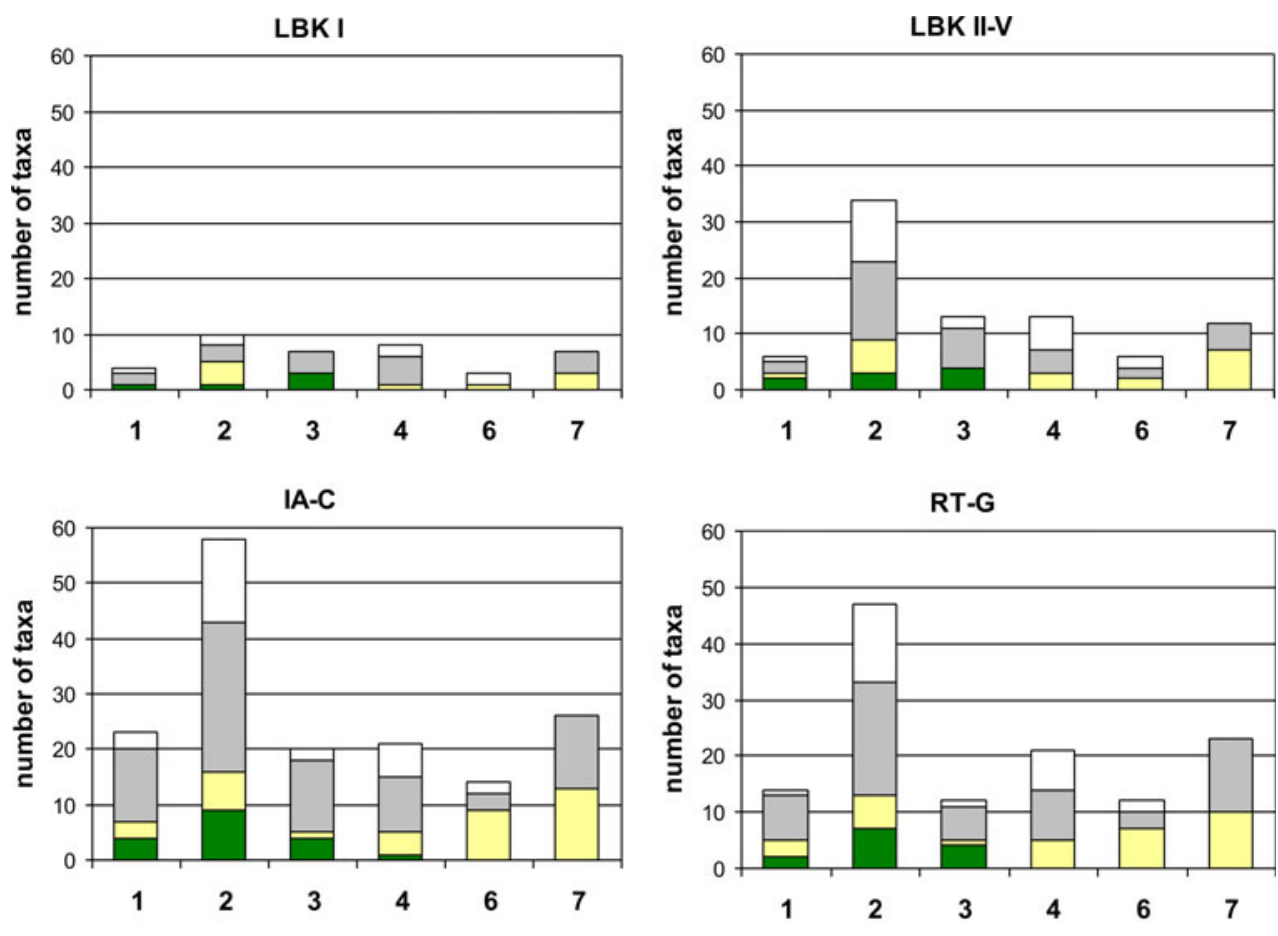

competitors $\square$ ruderals $\square$ strategic transition types 


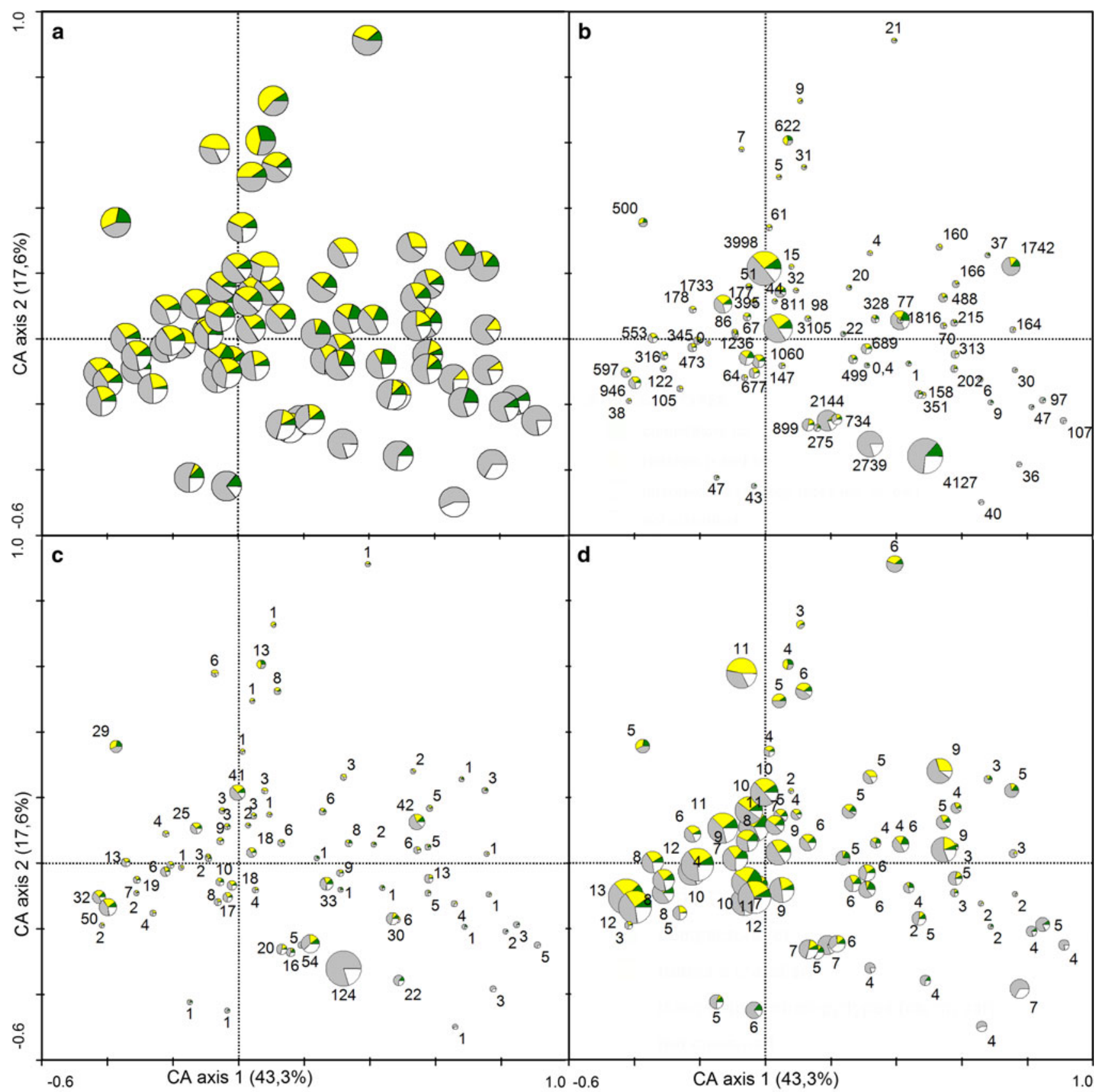

\section{STRATEGY TYPES}

competitors (c)

ruderals ( $r$ and $s r)$

Fig. 7 Correspondence analysis of the percentages of Strategy types of the potential weeds (number of species) per settlement site with the precondition of at least five weed species per site. a the sites (pie charts) unscaled. b scaled by the sample volume; the sample volumes (numbers in the diagram) have no essential influence on the distribution of the strategy types. c scaled by the number of features

pp. 197ff.). Because of their high seed productivity and effective form of spreading ruderals are able quickly to establish themselves on ploughed fields or intensively managed garden plots (Ecological Groups 4, 6 and 7, Table 1; Fig. 6). intermediate strategy types (cs, cr, csr)

not classified

(pits). The number of features per site (numbers in the diagram) has no essential influence on the distribution of the Strategy types. d scaled by the number of crop species per site. There is a relation between the numbers of crop species (numbers in the diagram) and the distribution of the Strategy types

On the other hand we have evidence for Bandkeramik weed species classified as competitors (Konkurrenzstrategen) regularly occurring together with cereal remains. Today they belong predominantly to the two ecological groups 1 Riparian/Floodplain Vegetation and 2 
"Grassland" and in parts to the ecological group 3 Ruderal Vegetation. The competitors amongst the weeds are perennial herbaceous species, often able to spread vegetatively. They are competitive species and it is important for the following interpretation that they need undisturbed, stable habitats for a longer time (Klotz and Kühn 2002, p. 197).

In addition there are strategical transition types including characteristics of both groups, ruderals and competitors. They cannot be interpreted in terms of our question of field management, but as they are part of the results they have been used for the calculations and later summed up in the correspondence analysis graphs (see below and Table 1).

We applied correspondence analysis to our data to gain an impression of the diachrone development of the kind and the diversity of strategy types. The correspondence analysis of the proportions of strategy types of the potential weed species per site (Fig. 7a) shows that the competitors, sensitive to disturbance, are present during all time periods. On the other hand it can be seen that the ruderals, needing highly disturbed stands, increase in the more recent prehistoric sites, on the left side of the graph. Like the rise in diversity of weed species mentioned above, this can be interpreted in terms of an intensification of field management developing over time.

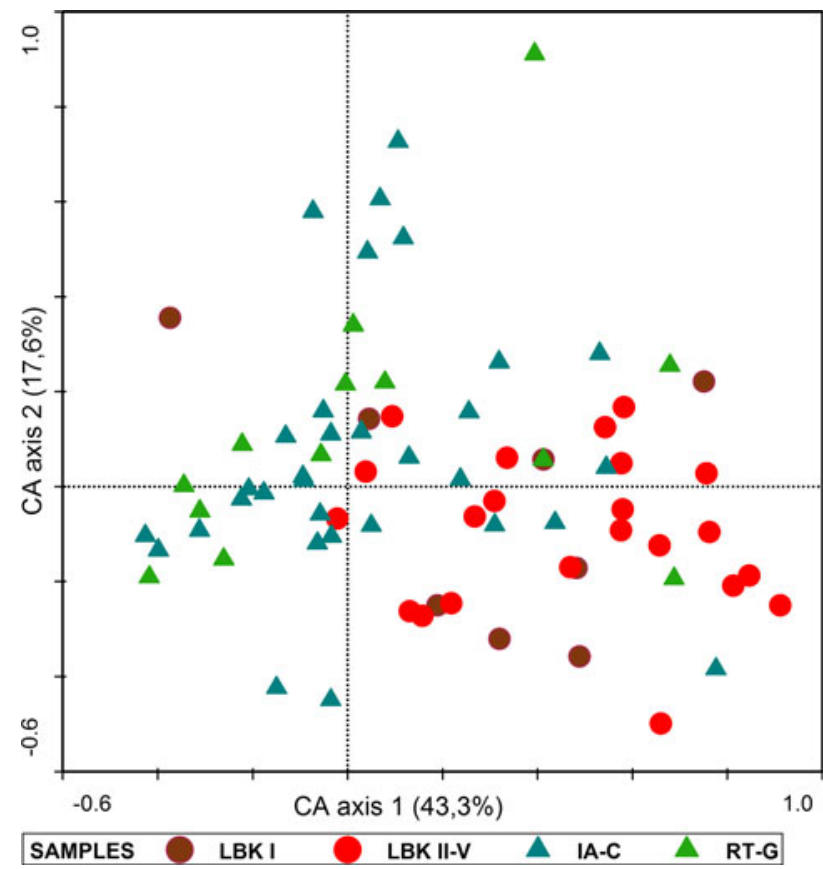

Fig. 8 The same CA as in Fig. 7. Here the settlement sites (symbols) are marked according to the archaeological dating of the sites. It is evident that the more recent prehistoric sites are distributed on the left side of the graph. Therefore there is a relation between the archaeological dating and the distribution of the Strategy Types
It was checked if this result was caused by methodological parameters alone. As shown in Fig. 7b, c, the distribution of the strategy types is neither dependant on the sample volume, or on the number of features analyzed. Instead there is a clear tendency for a causal connection of ruderal strategists with the archaeological dating of the sites and with the number of crop species grown (Figs. 7d, 8).

The presumed Bandkeramik field management with hoes, digging sticks or similar tools apparently does not differ qualitatively in its consequences for the weed flora from the later treatment with a simple ard plough. This explains why competitors needing undisturbed stands could survive on the fields over the millennia. Obviously during the more recent prehistoric periods habitat conditions were changed which allowed an increased establishment of ruderal strategy type weeds, maybe due to an intensification of field management in the form of intensified working of the land and weeding.

Acknowledgements This paper is dedicated to Karl-Ernst Behre to his 75 th birthday with many thanks for his useful scientific criticism and his professional advice in the past decades. We thank Stefan Klotz, UFZ Halle, for providing us with the BIOLFLOR data and the referees for their useful comments.

Open Access This article is distributed under the terms of the Creative Commons Attribution Noncommercial License which permits any noncommercial use, distribution, and reproduction in any medium, provided the original author(s) and source are credited.

\section{References}

Anderson PC, Cummings LS, Schippers TK, Simonel B (2003) Le traitement des récoltes. Éditions APDCA, Antibes

Arbogast R-M, Jeunesse C, Schibler J (2001) Rolle und Bedeutung der Jagd während des Frühneolithikums Mitteleuropas (Linearbandkeramik 5500-4900 v. J.-C.) Internat Archäol 1. Rahden/ Westf

Bakels CC (1978) Four Linearbandkeramik settlements and their environment: a palaeoecological study of Sittard, Stein, Elsloo und Hienheim. Analecta Praehist Leid 11, Leiden University Press, Leiden

Bates DG (1973) Nomads and farmers: a study of the Yörük of Southeastern Turkey. Anthropological papers 52, Ann Arbor

Behre K-E (1993) Die tausendjährige Geschichte des TeesdalioArnoseridetums. Phytocoenologia 23. Bornträger, Berlin, Stuttgart, pp 449-456

Behre K-E (1999) Vegetationsgeschichte und Paläoökologie-ihre Beiträge zum Verständnis der heutigen Vegetation. Berichte der Reinhold-Tüxen-Gesellschaft 11:245-266

Behre K-E, Jacomet S (1991) The ecological interpretation of archaeobotanical data. In: van Zeist W, Wasylikowa K, Behre K-E (eds) Progress in old world Palaeoethnobotany. Balkema, Rotterdam, pp 81-108

Benecke N (1994) Der Mensch und seine Haustiere. Die Geschichte einer Jahrtausende alten Beziehung, Theiss, Stuttgart

Blumler MA, Waines JG (2009) On the potential for spring sowing in the ancient Near East. In: Fairbairn AS, Weiss E (eds) From foragers to farmers. Oxbow Books, Oxford, pp 19-26 
Bogaard A (2002) Questioning the relevance of shifting cultivation to Neolithic farming in the loess belt of Europe: evidence from the Hambach Forest experiment. Veget Hist Archaeobot 11:155-168

Bogaard A (2004) Neolithic farming in Central Europe. An archaeobotanical study of crop husbandry practices. Routledge, London, New York

Brouwer W, Stählin A (1975) Handbuch der Samenkunde für Landwirtschaft. Gartenbau und Forstwirtschaft, DLG-Verlag, Frankfurt/M

Durka W (2002) Blüten- und Reproduktionsbiologie. In: Klotz S, Kühn I, Durka W (eds) BIOLFLOR-eine Datenbank mit biologisch-ökologischen Merkmalen zur Flora von Deutschland. Schriftenreihe für Vegetationskunde 38. Bundesamt für Naturschutz, Bonn, Bad Godesberg, pp 133-175

Ebersbach R (2002) Von Bauern und Rindern. Basler Beiträge zur Archäologie 15. Basel

Ellenberg H (1950) Landwirtschaftliche Pflanzensoziologie I: Unkrautgemeinschaften als Zeiger für Klima und Boden. Ulmer, Stuttgart

Ellenberg H, Weber HE, Düll R, With V, Werner W, Paulißen D (1991) Zeigerwerte von Pflanzen in Mitteleuropa. Scripta Geobotanica 18

Ertug-Yaras F (1997) An ethnoarchaeological study of subsistence and plant gathering in Central Anatolia, Diss. Washington University, St. Louis

Favre P (2002) Archäobotanik. In: Achour-Uster C, Eberli C, Ebersbach R, Favre P (eds) Die Seeufersiedlungen in Horgen. Die neolithischen und bronzezeitlichen Fundstellen Dampfschiffsteg und Scheller. Monographien der Kantonsarchäologie Zürich 36. Egg, Zürich, pp 150-181

Forbes H (1998) European agriculture viewed bottom-side upwards: fodder-provision in a traditional Greek community. In: Charles M, Halstead P, Jones G (eds) Fodder: archaeological, historical and ethnographic studies. Environ Archaeol 1:19-34

Fries JC (1995) Vor- und frühgeschichtliche Agrartechnik auf den Britischen Inseln und dem Kontinent. Eine vergleichende Studie. Internationale Archäologie 26. Leidorf, Espelkamp

Gregg SA (1988) Foragers and farmers: population interaction and agricultural expansion in prehistoric Europe. Prehistoric Archeology and Ecology, Chicago, London

Grime JP (1974) Vegetation classification by reference to strategies. Nature 250:26-31

Grime JP, Hodgson JG, Hunt R (1988) Comparative plant ecology: a functional approach to common British species. Unwin Hyman, London

Halstead P (1981) Counting sheep in Neolithic and Bronze Age Greece. In: Hodder I, Isaac G, Hammond N (eds) Pattern of the past, studies in honour of David Clarke. Cambridge University Press, Cambridge, pp 307-339

Hillman G (1984) Interpretation of archaeological plant remains: the application of ethnographic models from Turkey. In: van Zeist W, Casparie WA (eds) Plants and ancient man. Balkema, Rotterdam, Boston, pp 1-41

Holzer S (2008) Sepp Holzer's Permakultur. Praktische Anwendung für Garten, Obst und Landwirtschaft. Leopold Stocker, Graz, Stuttgart

Hüppe J, Hofmeister H (1990) Syntaxonomische Fassung und Übersicht über die Ackerunkrautgesellschaften der Bundesrepublik Deutschland. Berichte der Reinhold Tüxen-Gesellschaft 2:61-81

Jacomet S, Schibler J (2007) Experimente zur neolithischen Landwirtschaft... oder wie man aus Misserfolgen klug wird. http://pages.unibas.ch/arch/forschung/expland.htm

Jacomet S, Leuzinger U, Schibler J (2004) Die jungsteinzeitliche Seeufersiedlung Arbon Bleiche 3. Umwelt und Wirtschaft. Archäologie im Thurgau 12. Frauenfeld
Jones G (1984) Interpretation of archaeological plant remains: ethnographic models from Greece. In: van Zeist W, Casparie WA (eds) Plants and ancient man. Studies in palaeoethnobotany. Balkema, Rotterdam, Boston, pp 43-61

Jones G, Halstead P (1995) Maslins, mixtures und monocrops; on the interpretation of archaeobotanical crop samples of heterogeneous composition. J Archaeol Sci 22:103-114

Jones G, Charles M, Bogaard A, Hodgson JG, Palmer C (2005) The funtional ecology of present-day arable weed floras and its applicability for the identification of past crop husbandry. In: Buxó R, Jacomet S, Bittmann F (eds) Interaction between man and plants. New Progress in archaeobotanical research. Proceeding of the 13th IWGP symposium Girona, Spain, 2004. Veget Hist Archaeobot 14:493-504

Kästner A, Jäger E, Schubert R (2001) Handbuch der Segetalpflanzen Mitteleuropas. Springer, Wien, New York

Klotz S, Kühn I (2002) Ökologische Strategietypen. In: Klotz S, Kühn I, Durka W (eds) BIOLFLOR - eine Datenbank mit biologischökologischen Merkmalen zur Flora von Deutschland. Bundesamt für Naturschutz, Bonn, Bad Godesberg, pp 197-201

Klotz S, Kühn I, Durka W (2002) BIOLFLOR-eine Datenbank mit biologisch-ökologischen Merkmalen zur Flora von Deutschland. Bundesamt für Naturschutz, Bonn, Bad Godesberg

Knörzer K-H (1991) Deutschland nördlich der Donau. In: van Zeist W, Wasylikowa K, Behre K-E (eds) Progress in old world Palaeoethnobotany. Balkema, Rotterdam, pp 189-206

Korneck D, Sukopp H (1988) Rote Liste der in der Bundesrepublik Deutschland ausgestorbenen, verschollenen und gefährdeten Farn- und Blütenpflanzen und ihre Auswertung für den Artenund Biotopschutz. Schriftenreihe Vegetationskunde 19

Kreuz A (1993) Einheimische oder fremde Pflanzen? Überlegungen zur Herkunft "potentieller Unkräuter" und ihrer Verbreitung zur Zeit der Bandkeramik. In: Kalis AJ, Meurers-Balke, J (eds) 7000 Jahre bäuerliche Landwirtschaft: Entstehung, Erforschung, Erhaltung. Archaeo-Physika 13:23-33

Kreuz A (2005) Landwirtschaft im Umbruch? Archäobotanische Untersuchungen zu den Jahrhunderten um Christi Geburt in Hessen und Mainfranken. Ber RGK 80:97-292

Kreuz A (2007) Archaeobotanical perspectives on the beginning of agriculture north of the Alps. In: Colledge S, Conolly J (eds) Archaeobotanical perspectives on the origin and spread of agriculture in southwest Asia and Europe. Left Coast Press, Walnut Creek, pp 259-294

Kreuz A (in press) Die Vertreibung aus dem Paradies? Archäobiologische Ergebnisse zum Frühneolithikum in Mitteleuropa. Ber RGK 90

Kreuz A, Schäfer E (2008) Archaeobotanical considerations of the development of Pre-Roman Iron Age crop growing in the region of Hesse, Germany, and the question of agricultural production and consumption at hillfort sites and open settlements. Veget Hist Archaeobot 17(Suppl 1):159-179

Kreuz A, Marinova E, Schäfer E, Wiethold J (2005) A comparison of Early Neolithic crop and weed assemblages from the Linearbandkeramik and the Bulgarian Neolithic cultures: differences and similarities. Veget Hist Archaeobot 14:237-258

Lüning J (2000) Steinzeitliche Bauern in Deutschland. Die Landwirtschaft im Neolithikum. Univ Forsch Prähist Archäol 58

MacArthur RH, Wilson EO (1967) The theory of island biogeography. Princeton University Press, Princeton

Maier U (1999) Agricultural activities and land use in a Neolithic village around 3900 B.C.: Hornstaad Hörnle I A, Lake Constance, Germany. Veget Hist Archaeobot 8:87-94

Meier-Arendt W (1966) Die Bandkeramische Kultur im Untermaingebiet. Darmstadt

Oberdorfer E (1990a) 2001) Pflanzensoziologische Exkursionsflora für Deutschland und angrenzende Gebiete. Ulmer, Stuttgart 
Oberdorfer E (1990b) Pflanzensoziologische Exkursionsflora für Deutschland und angrenzende Gebiete. Ulmer, Stuttgart

Pflanzliche Erzeugung Band 1 (1998) Die Landwirtschaft. BLV Verlagsgesellschaft mbH. München, Wien, Zürich

Procopiou H, Treuil R (2002) Moudre et Broyer. L'interprétation fonctionelle de l'outillage de mouture et de broyage dans la Préhistoire et l'Antiquité. 1. Méthodes: pétrographie, chimie, tracéologie, expérimentation, ethnoarchéologie. 2. Archéologie et Histoire: du Paléolithique au Moyen Âge. Actes de la Table Ronde Internationale, Clermont-Ferrand, 30 nov.-2 déc.1995. CTHS, Paris

Reynolds PJ (1979) Iron-age farm. The Butser experiment, London

Rösch M (2005) Anbauversuche in Hohenlohe - Fragestellung, wissenschaftlicher Ansatz. In: Regierungspräsidium Stuttgart LfD (ed) $\mathrm{Zu}$ den Wurzeln europäischer Kulturlandschaftexperimentelle Forschungen. Wissenschaftliche Tagung Schöntal 2002. Materialhefte zur Archäologie in Baden-Württemberg 73. Theiss, Stuttgart, pp 67-82

Sherratt A (1981) Plough and pastoralism: aspects of the secondary products revolution. In: Hodder I, Isaac G, Hammond N (eds)
Pattern of the past. Cambridge University Press, Cambridge, pp 261-305

Sherratt A (1983) The secondary exploitation of animals in the Old World. World Archaeol 15(1):90-104

Stika H-P (1999) Approaches to reconstruction of early Celtic landuse in the central Neckar region in southwestern Germany. Veget Hist Archaeobot 8:95-103

Ter Braak CJF, Šmilauer P (2002) CANOCO 4.5 reference manual. Biometrics, Wageningen/České Budějovice

Van der Veen M (2005) Gardens and fields: the intensity and scale of food production. In: van der Veen M (ed) Garden agriculture. World Archaeol 37:157-163

Willerding U (1980) Zum Ackerbau der Bandkeramiker. In: Krüger T, Stephan HG (eds) Beiträge zur Archäologie Nordwestdeutschlands und Mitteleuropas. Materialhefte zur Ur- und Frühgeschichte Niedersachsens 16:421-457

Willerding U (1988) Zur Entwicklung von Ackerunkrautgesellschaften im Zeitraum vom Neolithikum bis in die Neuzeit. In: Küster $\mathrm{H}$ (ed) Der prähistorische Mensch und seine Umwelt. Theiss, Stuttgart, pp 31-41 